\title{
Added value of panda alami jackfruit chips in Cipadang Sub Dictrict, Pesawaran Regency, Lampung, Indonesia
}

\author{
S Fafrina $^{1^{*}}$, FM Saty $^{2}$ and Sutarni ${ }^{2}$ \\ ${ }^{1}$ Departement of Food Agribusiness, Economics and Business, Politeknik Negeri \\ Lampung, Bandar Lampung, Indonesia \\ ${ }^{2}$ Departement of Food Agribusiness, Economics and Business, Politeknik Negeri \\ Lampung, Bandar Lampung, Indonesia
}

*Corresponding author: sinta.fafrina@yahoo.co.id

\begin{abstract}
The processing of jackfruit into food products aims to improve the durability of jackfruit that feasible to be consumption and give added value. The Panda Alami jackfruit chips business is one of the industries that process jackfruit into jackfruit chips. This business is expected to improve the quality, profitability and added value of the product. The purpose of this study is to determine the revenue and added value obtained from the processing of Panda Alami jackfruit chips in Cipadang Village, Gedong Tataan District, Pesawaran Regency. The techniques used to collect the data was done by observation through obtaining data by making direct observations to the object of research. The data collected includes primary data and secondary data. The method used in this study is a descriptive method which is to know the general description of the Panda Alami jackfruit chip business and the quantity method that is the value-added analysis. The value-added analysis of Panda Alami jackfruit chips used the Hayami method. The research results showed that received a positive added value of $\mathrm{Rp}$ $1.862,00$ for $1 \mathrm{~kg}$ of jackfruit. The added value ratio was $22,16 \%$, with a profit rate of $64,14 \%$ from the product value.
\end{abstract}

\section{Introduction}

Jackfruit is a tropical fruit that has not received priority, both regional and national levels, but has the potential to be developed on an agribusiness scale. So far, the general public has grown jackfruit only as a shade plant in the yard or as an intercropping plant in the garden. It is still rare for farmers to cultivate jackfruit specifically (Rukmana, 2002).

The Central Bureau of Statistics (2018) explained that jackfruit production in Lampung in 2016 and 2017 was in the fifth position out of 34 provinces. In 2016, Jackfruit production in Lampung has reached 42.036 tons. In 2017, there was a decrease in production that has reached only 40.163 tons, meanwhile, in 2018, there was an increase in jackfruit production that increased to 40.246 tons. The high production of jackfruit in Lampung has the potential to be developed into a processing business, one of which is jackfruit chips. This situation is the same as the amount of production in Pesawaran District.

Jackfruit which is processed into chips has a bright prospect because jackfruit chips are well known to the public and a lot of people like it. Laeliyah (2018), explains that agricultural product processing aims to extend durability and storage capacity and can increase added value to these agricultural commodities. This can be seen in Picture 1 which shows the data on the production of jackfruit chips 
from 2014-2019. This data shows that the consumption of jackfruit chips has increased every year. The increase in consumption shows an increase in demand for jackfruit chips in the Lampung area (Food Crops and Horticulture Office of Lampung Province, 2019).

Agricultural products that are processed into finished or semi-finished goods are expected to provide added value so that the selling price of these agricultural products increases. The added value of a product is obtained by increasing the use value of the product by doing innovation. One of the business that make jackfruit to jackfruit chips is the Panda Alami Chips Business.

The Panda Alami Chips Business produces raw materials for 1.500-2.500 kg of jackfruit per month. The uniqueness and superiority of the Panda Alami jackfruit chips with other chips business is that the production process uses modern equipment, namely a vacuum frying machine. The products produced by Panda Alami chips are good, well packaged and have a security label, namely "halall certificate and a P-IRT number". The increasing demand for chips has spurred the Panda Alami Chips business to maintain consumer confidence and maintain product quality. Producers must have the advantage to be able to attract consumers. The Panda Alami chips business must meet consumer demand by producing quality and competitive products. The following is a table of Panda Alamii jackfruit chips production in 2014-2019 can be seen in the Figure 1.

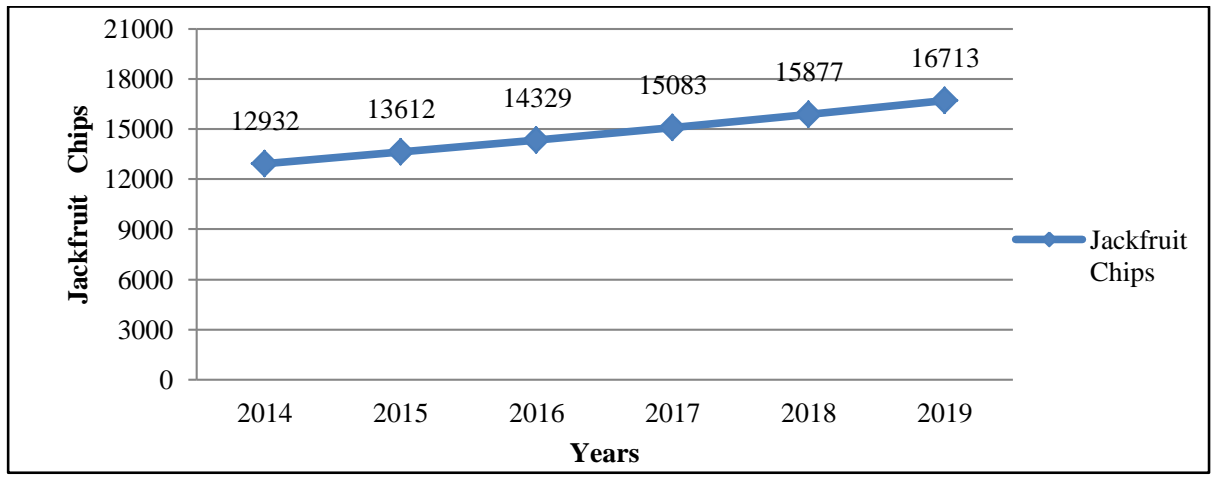

Figure 1. Panda Alami jackfruit chips production in 2014-2019 (Kg) Source: UD Panda Alami processed by researchers, 2019

Picture 1 explains that production Jackfruit chips in the Panda Alami business from 2014 to 2019 have increased every year. The jackfruit chips are marketed directly to the distributor of souvenir shops in Bandar Lampung, namely Aska Jaya, Banana Foster, Yusi Akmal, Yen-Yen, and Transmart Lampung. The market share of Panda Alami jackfruit chips has penetrated to Java, namely Jakarta, Sentul, Bogor, Bandung, Cikampek, with a distribution quantity of 2.500-3.000 packs of jackfruit chips in a period of 10 days.

Activities in industry that change primary forms into new products will experience an increase in economic value, this is due to the processing that add production input so that other costs that caused new higher costs are formed, and also generate greater profits if compared to raw products without processing (Haq and Wulandari, 2020). The jackfruit chip business is generally small in scale, while the number of jackfruit chip entrepreneurs from year to year does not increase due to a lack of raw materials. The jackfruit raw material is still relatively difficult because the production pattern of jackfruit is still sporadic and has not yet become the main farm. The scarcity of jackfruit raw materials is a determining factor in the sustainability of the jackfruit chips business in Lampung. The scarcity of raw materials can also affect the turnover and profits that the Panda Alami jackfruit chips business will get in the long run.

The added value of processing agricultural commodities is a reward for producers in the form of revenue and profits. With the benefits obtained, the producers have the capital to be able to maintain the continuity of activities and business development. The raw material for jackfruit that is processed into jackfruit chips also contributes to the income of the surrounding community by absorbing labor 
from the surrounding environment, so that it can be an alternative to reducing unemployment in Cipadang Village, Gedong Tataan.

Imran, et al. (2014) explained that agricultural product processing is a series of agribusinesses that play a role in increasing the added value of agricultural products. The added value of processing jackfruit into jackfruit chips is also important to analyze to determine the magnitude of the social impact, namely the effect on labor absorption in the surrounding environment, remuneration received by workers, and industrial managers in processing raw materials until jackfruit chips are sold. The prospective Panda Alami business will help to increase economic value and this economic activity can open up job opportunities for the surrounding community, so that the surrounding economy will increase. This shows that there is a social role to the environment around the Panda Alami business. Therefore, it is necessary to analyze the amount of added value obtained from the processing of jackfruit into chips, both economically and socially.

\section{Material and Method}

This research was conducted in the Panda Alami Chips business located in Cipadang Village, Gedong Tataan District, Pesawaran Regency. The Panda Alami chips business is the only place that produces jackfruit chips in Cipadang village. The research was conducted in October 2019 - January 2020.

The data used are primary and secondary data. Primary data obtained through observation and interviews, while secondary data were obtained through related institutions/agencies such as the Central Bureau of Statistics, the Office of Cooperatives for Industry and Trade of Pesawaran District, and other related institutions/agencies regarding the number of industry players, industrial identity, and other literature related to this research.

The method used in this research are descriptive qualitative analysis and quantitative analysis. The data analysis method is to count the revenue and added value. The added value counted by using hayami method, the formula as describes in Table 4 (Sudiyono, 2004). The revenue counts used the formula as desribes below (Soekartawi, 2000):

Descripsion:

$$
\begin{gathered}
\mathrm{Y}=\mathrm{TR}-\mathrm{TC} \\
\mathrm{TR}=\mathrm{P} \cdot \mathrm{Q} \\
\mathrm{TC}=\mathrm{TFC}+\mathrm{TVC}
\end{gathered}
$$

$\mathrm{Y}=$ income $(\mathrm{Rp})$

$\mathrm{TR}=$ total revenue $(\mathrm{Rp})$

$\mathrm{TC}=$ total cost $(\mathrm{Rp})$

$\mathrm{P}=$ product price $(\mathrm{Rp})$

$\mathrm{Q}=$ quantity product $(\mathrm{Rp})$

$\mathrm{TFC}=$ total fixed cost $(\mathrm{Rp})$

$\mathrm{TVC}=$ total variable cost $(\mathrm{Rp})$

\section{Results and Discussion}

\subsection{General description}

Panda Alami Chips are jackfruit and banana chips processing business in Gedong Tataan District, Pesawaran Regency. Panda Alami Chips was founded by Mr. Muhadi in 1998. This is the largest jackfruit chip industry in Gedong Tataan District, Pesawaran Regency and has a raw material capacity of $800 \mathrm{~kg}$ per production. Panda Alami Chips has 19 workers who are outside the family labor. The flow chart of the Panda Alami jackfruit chips manufacturing process can be seen in Figure 2 


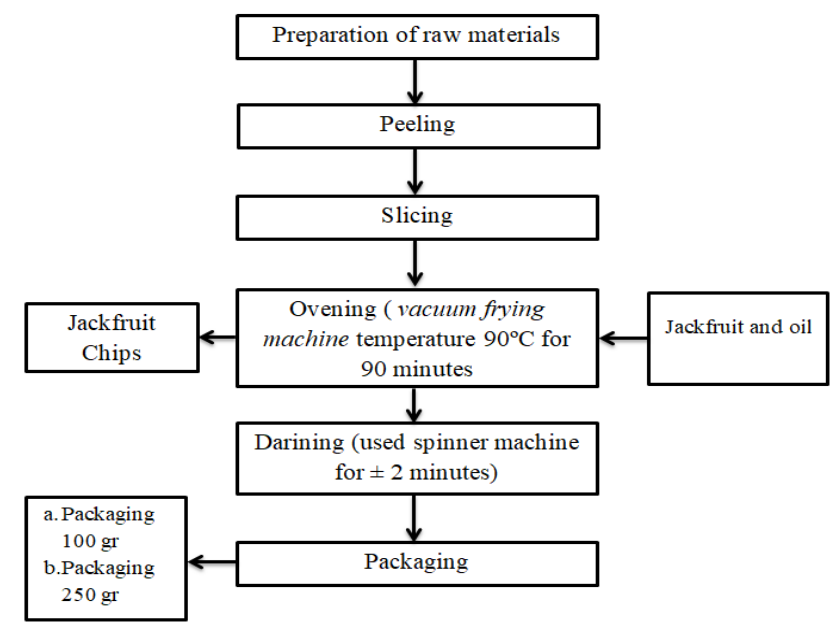

Figure 2. The flow chart of the Panda Alami jackfruit chips manufacturing process

In the process of processing jackfruit chips, there are several activities, namely stripping, slicing, frying with a vacuum frying machine, and packaging. The stripping and slicing activities are given a wage of Rp 23.000,00, while for packaging the wage given is $\mathrm{Rp} 40.000,00$, and for frying with a vacuum frying machine, $\mathrm{Rp} 70.000,00$.

\subsection{Cost and revenue analysis}

Fixed costs are costs whose use is not influenced by the amount of output produced, including supporting equipment in processing Panda Alami jackfruit chips. The calculation of the fixed costs of the Panda Alami jackfruit chips business can be seen in Table 1.

Table 1. The fixed costs of the Panda Alami jackfruit chips business

\begin{tabular}{|c|c|c|}
\hline No. & Detailed & Total Cost (Rp) \\
\hline 1. & Land and buildings & 181.000 .000 \\
\hline 2. & Production tools and machines & 301.802 .000 \\
\hline 3. & Office supplies & 6.100 .000 \\
\hline 4. & Other costs & 8.312 .000 \\
\hline Total & & 497.214 .000 \\
\hline
\end{tabular}

Source: UD Panda Alami processed by researchers, 2020

Variable costs are costs which are influenced by the amount of production and are disposable. Variable costs in the Panda Alami jackfruit chip business consist of variable costs and labor costs. The calculation of variable costs for the Panda Alami jackfruit chips business can be seen in Table 2.

Table 2.Variable costs for the Panda Alami jackfruit chips business (2019)

\begin{tabular}{clrrr}
\hline No. & \multicolumn{1}{c}{ Detailed } & $\begin{array}{c}\text { Total Cost / } \\
\text { Production }(\mathrm{Rp})\end{array}$ & $\begin{array}{c}\text { Total Cost / Month } \\
(\mathrm{Rp})\end{array}$ & $\begin{array}{c}\text { Total Cost / Year } \\
(\mathrm{Rp})\end{array}$ \\
\hline 1. & Raw material costs & 2.240 .000 & 56.000 .000 & 672.000 .000 \\
2. & Factory overhead costs & 2.262 .569 & 56.564 .236 & 678.770 .832 \\
3. & Marketing costs & 2.943 .667 & 9.841 .667 & 118.100 .004 \\
4. & Labor costs & 546.000 & 10.225 .000 & 122.700 .000 \\
& HOK & & 243,25 & \\
\hline Total & & 7.992 .236 & 132.630 .903 & 1.591 .570 .836 \\
\hline
\end{tabular}

Source: UD Panda Alami processed by researchers, 2020 
The total variable cost of producing jackfruit chips per year is $\mathrm{Rp} 1.591 .570 .836,00$. Revenue is calculated using the amount of production and the price of the jackfruit chips. The average production of Panda Alami jackfruit chip business is $796 \mathrm{~kg}$ per day, while the average production per day is 56 $\mathrm{kg}$. Besides, the average production per month using input $19.896 \mathrm{~kg}$ resulting the output of $1.393 \mathrm{~kg}$. The ratio of input to output in the production process of jackfruit chips in $1 \mathrm{~kg}$ of jackfruit will turn into jackfruit chips as much as $0,07 \mathrm{~kg}$ or $1: 0,07$, there is a yield of $7 \%$. There are two kinds of jackfruit chips, namely 100 gram and 250 gram in size, the percentage of each packaging is $50 \%$ of the total production. The price of the Panda Alami jackfruit chips is Rp12.000,00 per 100 grams and Rp $30.000,00$ per 250 grams, while the jackfruit chips per $\mathrm{kg}$ are sold at $\mathrm{Rp} 120.000,00$. The calculation of business revenue for Panda Natural jackfruit chips can be seen in Table 3.

Table 3. Business revenue for Panda Alami jackfruit chips (year 2019)

\begin{tabular}{rlcrc}
\hline No. & Detailed & Quantity (packaging) & Price $(\mathrm{Rp})$ & Revenue $(\mathrm{Rp})$ \\
\hline 1. & Packaging 100 grams & 33.425 & 12.000 & 1.002 .750 .000 \\
2. & Packaging 250 grams & 83.563 & 30.000 & 1.086 .312 .500 \\
\hline Total & 116.988 & & 2.005 .500 .000 \\
\hline
\end{tabular}

Source: UD Panda Alami processed by researchers, 2020

\subsection{Added value analysis}

The existence of a business can affect the environment, both the community environment and the ecological environment where the business will be run. Business activities can have an impact on the environment around the business location, especially social and economic changes. Communities who will have a positive impact will support the existence of the business being carried out. Conversely, people who feel the negative impact of the existence of a business is greater than the positive impact will reject the existence of the business. The Panda Alami jackfruit chip business has opened up job opportunities for local residents. There are 17 workers from local residents who work in the Panda Alami Chips business.

This business has a minimal workforce amounting to 19 people, however this opportunity is sufficient to increase employment opportunities for the surrounding community. The average remuneration per day given to workers is Rp 54.600,00/person. The health insurance received by workers is that if the worker is injured due to a work accident due to machines or other work equipment, the business owner will bear the medical costs. Moreover, the Panda Alami jackfruit chip business has contributed significantly to the construction of public facilities and donations. If there is a construction of public facilities, such as building a mosque, repairing roads, the Panda Alami Chips business will give contribution so that the construction could run smoothly.

Processing of agricultural products is intended to increase income and added value from these products. The processing of jackfruit into jackfruit chips is an activity that can generate added value and drive the economy in Cipadang Village. Changing fresh forms to processed forms can increase added value such as cassava chips products (Hartoyo, 2019). The Panda Alami jackfruit chip business is also a unique business because not all of them can do this business since this business using vacuum frying machine in the processing step. The results of the analysis of the added value of jackfruit into jackfruit chips in the Panda Alami Chips business can be seen in Table 4.

Table 4. Calculation of the added value of the Panda Natural jackfruit chips business

\begin{tabular}{lllr}
\hline No. & Variable & Formula & Value \\
\hline I. Output, Input and Price & & 1.393 \\
\hline 1 & Output (Kg/month) & 1 & 19.896 \\
2 & Input (Kg/month) & 2 & 243,25 \\
3 & Labor (HOK/month) & 3 & 0,07 \\
4 & Conversion Factor & $(4)=1 / 2$ & 0,012 \\
5 & Labor Coefficient & $(5)=3 / 2$ & \\
\hline
\end{tabular}




\begin{tabular}{|c|c|c|c|}
\hline 6 & Output Price $(\mathrm{Rp} / \mathrm{Kg})$ & 6 & Rp 120.000 \\
\hline 7 & Wages of Labor (Rp) (HOK) & 7 & Rp 54.600 \\
\hline \multicolumn{4}{|c|}{ II. Revenue and Profits } \\
\hline 8 & Raw Material Price $(\mathrm{Rp} / \mathrm{Kg})$ & 8 & $\operatorname{Rp} 2.800$ \\
\hline 9 & Other Input Contribution $(\mathrm{Rp} / \mathrm{Kg})$ & 9 & $\operatorname{Rp} 3.738$ \\
\hline 10 & Output Value $(\mathrm{Rp} / \mathrm{Kg})$ & $(10)=4 \times 6$ & $\operatorname{Rp} 8.400$ \\
\hline \multirow[t]{2}{*}{11} & a. Added Value $(\mathrm{Rp} / \mathrm{Kg})$ & $(11 \mathrm{a})=10-9-8$ & Rp 1.862 \\
\hline & b. Value Added Ratio $(\mathrm{Rp} / \mathrm{Kg})$ & $(11 b)=(11 a / 10) \times 100$ & $22,16 \%$ \\
\hline \multirow[t]{2}{*}{12} & a. Labor Income $(\mathrm{Rp} / \mathrm{Kg})$ & $(12 a)=5 \times 7$ & Rp 668 \\
\hline & b. Share of Labor (\%) & $(12 b)=(12 a / 11 a) \times 100$ & $35,86 \%$ \\
\hline \multirow[t]{2}{*}{13} & a. Profit $(\mathrm{Rp} / \mathrm{Kg})$ & $(13 a)=11 a-12 a$ & Rp 1.194 \\
\hline & b. Profit Rate (\%) & $(13 b)=(13 a / 11 a) \times 100$ & $64,14 \%$ \\
\hline \multirow[t]{4}{*}{14} & $\operatorname{Margin}(\mathrm{Rp} / \mathrm{Kg})$ & $(14)=10-8$ & $\operatorname{Rp} 5.600$ \\
\hline & a. Labor Income & $(14 a)=(12 a / 14) \times 100$ & $11,92 \%$ \\
\hline & b. Other Input Contribution & $(14 b)=(9 / 14) \times 100$ & $66,75 \%$ \\
\hline & c. Entrepreneur Profit & $(14 c)=(13 a / 14) \times 100$ & $21,33 \%$ \\
\hline
\end{tabular}

Source: UD Panda Alami processed by researchers, 2020

Table 4 describes the calculation of added value the basis of calculation in this analysis is the added value for each kilogram of raw material for jackfruit chips in one month of production. The raw materials used in the production process for one month were $19.896 \mathrm{~kg}$ of jackfruit. The raw material will obtain a conversion factor of 0,07 . It means that every $1 \mathrm{~kg}$ of raw material of jackfruit will produce $0,07 \mathrm{~kg}$ of jackfruit chips. The total output produced from $19.896 \mathrm{~kg}$ of jackfruit is $1.393 \mathrm{~kg}$ of jackfruit chips, where the output price is Rp 120.000,00 / kg.

The labor coefficient is obtained from the ratio between the numbers of workers involved in the working person day (HOK) with the amount of raw materials processed. The average workforce involved in the processing of jackfruit chips is $243,25 \mathrm{HOK}$ per month with a labor coefficient of 0,012 . This labor coefficient value shows that the amount of HOK needed to process $1 \mathrm{~kg}$ of jackfruit into jackfruit chips is 0,012 . The raw material price for jackfruit is $\mathrm{Rp} 2.800,00 / \mathrm{kg}$.

The output value achieved in the processing of jackfruit chips is $\mathrm{Rp} 8.400,00 / \mathrm{kg}$. This value is the result of multiplying the conversion factor of raw materials into products with the value of the resulting product that can be used to calculate the gross receipt of jackfruit chips resulting from processing every $1 \mathrm{~kg}$ of the main raw material. The output value allocated for raw materials is

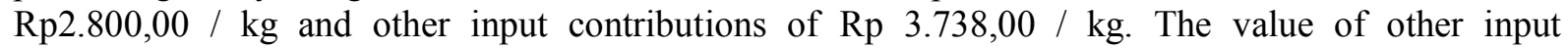
contributions consisting of the cost of supporting raw materials and the imposition of costs on the input contribution.

The added value generated from the processing of jackfruit into jackfruit chips is Rp 1.862,00 for every $1 \mathrm{~kg}$ of jackfruit which is the difference between the output value and the raw material and other input contributions. The ratio of added value obtained is $22,16 \%$ indicating the percentage of added value to the output value, meaning that every Rp 100,00 the output value will get an added value of Rp22,16. This means that the Panda Alami jackfruit business is feasible to be continued and developed, although the availability of jackfruit is currently still limited but jackfruit produces added value after the production process is carried out. This is in accordance with Hutapea's research (2020) which states that the jackfruit chip business at UD Tamita, in Muliorejo Village, Sunggal District, Deli Serdang Regency also produces added value and is feasible to be developed. It is also inaccordance with the research of Yolandika, et al. (2017) in their research of horticultural crops, namely broccoli which is packaged to produce added value.

The profit obtained based on the value added analysis of the jackfruit chip processing process is Rp $1.194,00$ with a profit rate of $64,14 \%$ of the product value. The profit value is the difference between added value and employee benefits. This advantage is a net added value as well as a reward for the processing industry. The results of the value added analysis obtained the gross profit margin from the processing of jackfruit chips. The gross profit margin obtained from the value of the product minus the 


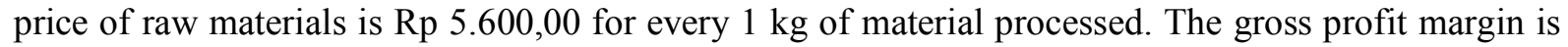
distributed for produiction factors, namely labor, the contribution of other inputs, and the net profit from the industry.

Remuneration obtained from labor production factors is $11,92 \%$. The remuneration for these workers is a reward for the relatively small processing workforce. Rahmi and Trimo (2019) explains that the margin distribution of labor income is the smallest due to the condition that the business still uses relatively little labor in the production process. The remuneration obtained for other input contributions is $66,75 \%$ of the gross profit margin, while the remuneration obtained for the profit is $21,33 \%$. This situation shows that the profits from the Panda Alami chips business greatly affect the gross profit margin of the processing of jackfruit chips. The net profit obtained, which is $21.33 \%$, is a reward for the business carried out and can be used to develop the Panda Alami jackfruit chip business.

\section{Conclusions}

The value added result of processing jackfruit into jackfruit chips is $\mathrm{Rp} 1.862,00$ for every $1 \mathrm{~kg}$ of jackfruit, with the added value ratio obtained is $22,16 \%$ indicating the percentage of added value to the output value. It means every $\mathrm{Rp} \mathrm{100,00} \mathrm{the} \mathrm{output} \mathrm{value} \mathrm{will} \mathrm{get} \mathrm{an} \mathrm{added} \mathrm{value} \mathrm{of} \mathrm{Rp} 22,16$. Remuneration obtained from labor production factors is $11,92 \%$. The workers remuneration is a reward for processing workers or also known as labor income. This means that the Panda Alami jackfruit business is feasible to be continued and developed, although the availability of jackfruit is currently still limited, but jackfruit will produce added value after the production process is carried out. The Panda Alami jackfruit chip business is also a unique business because not all people can do this business since this business used vacuum frying machine in the processing step.

\section{References}

[1] Food Crops and Horticulture Office of Lampung Province, 2019. Jackfruit Production in Pesawaran District. Food Crops and Horticulture Office of Lampung Province. Lampung.

[2] Haq, Q A and Wulandari, E. 2020. Analysis of Potato Value Add (Solanum tuberosum) in Cikanjang Sub-District Garut District. Journal of Agribusiness Insight Scientific Society Thought. Volume 6 (2):532-541

[3] Hutapea, Kenal P. 2020. Added Value and Profitability of Jackfruit Chips. Journal of Professional Stindo. Volume 6 (1) ISSN: 2443-0536.

[4] Imran, S., A. Murtisari, dan N.K. Murni. 2014. Analysis of the added value of cassava chips in Barokah UKM, Bone Bolango Regency. Journal of Regional Financing and Development Perspectives. Volume 1 Number 4.

[5] Laeliyah, L and Januar, J. 2018. Analysis of Added Value of Jackfruit Chips in UD Dua Dewi Agroindustry in Jember Regency. National Seminar on Agribusiness Study Program, Faculty of Agriculture, University of Jember.

[6] Rahmi, I and Trimo, L. 2019. Added Value of Agroindustry Dodol Tomat (Case Study of Agroindustry Dodol Tomat in Genteng Village, Sukasari Sub-District, Sumedang City). Journal of Food System and Agribusiness. Volume 3 Number 1: 1-7.

[7] Rukmana, R. 2002. Leading Commodities and Prospects of Agribusiness. Kanisius. Yogyakarta.

[8] Soekartawi. 2000. Introduction to Agro-Industry. PT Raja Grafindo Persada. Jakarta.

[9] Sudiyono, A. 2004. Agricultural Marketing. UMM Press. Malang.

[10] The Central Bureau of Statistics. 2018. Annual Fruit and Vegetable Crop Statistics. The Central Bureau of Statistics. Jakata.

[11] Yolandika, C., Nurmalina, R., Suharno. 2017. Analysis of Added Value of Packaged Broccoli CV. Yan's Fruits and Vegetable in Lembang District, West Bandung. Journal of Food System and Agribusiness. Volume 1 Number 1: 30-37.

[12] Hartoyo, Koswara, S., Sulassih., Megawati, L R., The Added Value Improvement of Banana 
Chips Business in Tenajar Village, Indramayu District, West Java. Scientific Journal of Community Service. Volume 5 (3):251-257. 